\title{
THE ELECTROPHORETIC PATTERN IN MULTIPLE MYELOMATOSIS
}

\author{
BY \\ LOUIS L. GRIFFITHS AND V. ANNE L. BREWS \\ From the Department of Pathology, Farnborough Hospital, Kent
}

(RECEIVED FOR PUBLICATION MARCH 16, 1953)

Muitiple myelomatosis is a disease characterized by the formation of tumours composed of abnormal plasma cells originating in the bone marrow. The disease is unique in that Bence Jones protein occasionally appears in the urine of patients suffering from this condition.

The first full investigation by Perlzweig, Delrue, and Geschickter (1928) by the Howe (1921) method of fractionation was rapidly followed by further reports. In 1940 Bing reported on 36 cases, and in 1941 Gutman, Moore, and Kabat investigated a further 43 cases. The description of electrophoretic methods (Tiselius, 1939-40) provided a new method of approach. Longsworth, Shedlovsky, and MacInnes (1939) described three cases, Kekwick (1940) five, and Gutman, Moore, Gutman, McClellan, and Kabat (1941) 15 more. The position has been admirably reviewed by Gutman (1948) and by Marrack and Hoch (1949).

Gutman et al. (1941) have classified the sera from these patients into three types: (I) Sera with an increased gamma globulin fraction; (II) sera with increased beta fractions or fractions lying between the beta and gamma components, the socalled $\mathrm{M}$ fraction ; and (III) sera with apparently normal patterns. Moore, Kabat, and Gutman (1943) reported an unusual case in which the alpha globulin fraction was increased to $23 \%$, but there was in addition a beta component of $33 \%$. Wuhrmann, Wunderly, and Wiedemann (1948) have described two similar cases. In most instances there has been an associated decrease in the albumin fraction.

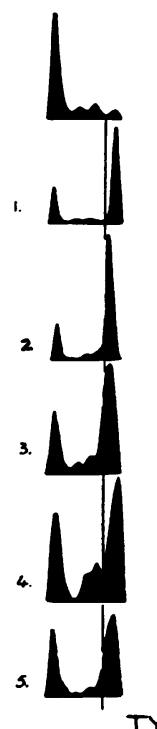

Filter paper electrophoresis has provided a new method of investigation into the chemistry of serum proteins. The results, although similar to the classical Tiselius method are not necessarily identical, especially with abnormal sera (Flynn and de Mayo, 1951). So far no description of any investigation of a series of multiple myelomata by this method has appeared.

We record the results obtained in 20 cases where the diagnosis in each case has been confirmed by finding the characteristic cells either by biopsy or at necropsy.

The technique used was similar to that previously described (Griffiths, 1952 and 1953).

Fig. 1 shows the electrophoretic patterns of the 20 sera investigated and also the patterns obtained
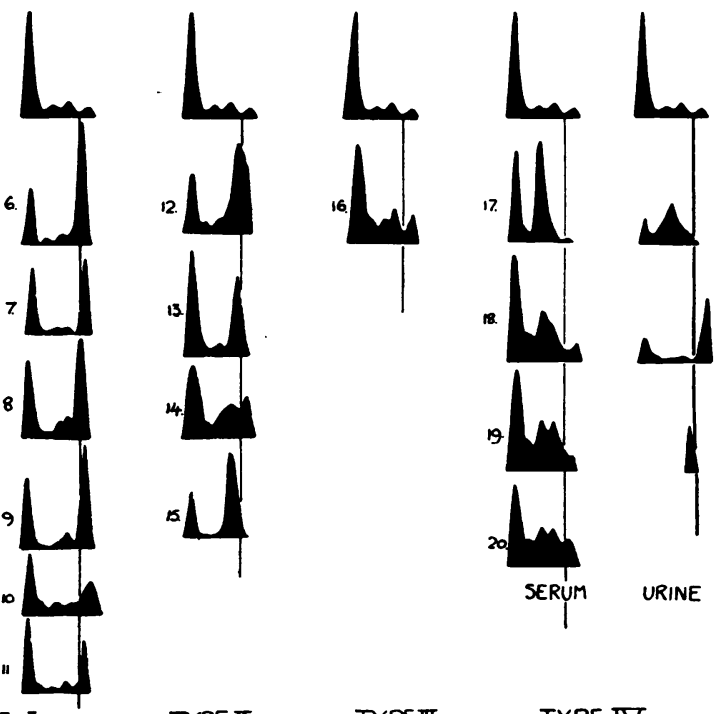

TYPE I

TYPE II

TYPEII

TYPE IV

Electrophoretic patterns calculated from filter paper strips (Griffiths, 1953). 
TABLE I

VALUES FOR 20 SERA

\begin{tabular}{|c|c|c|c|c|c|c|c|c|c|c|c|c|c|c|c|c|}
\hline \multirow{2}{*}{$\begin{array}{l}\text { Case } \\
\text { No. }\end{array}$} & \multirow{2}{*}{$\begin{array}{c}\text { Total } \\
\text { Protein } \\
\text { (g. } 100 \mathrm{ml} \text { ) }\end{array}$} & \multirow{2}{*}{\multicolumn{2}{|c|}{$(\%$ Albumin }} & \multicolumn{12}{|c|}{ Globulin $(\% \mathrm{~g} .100 \mathrm{ml})$} & \multirow{2}{*}{$\begin{array}{c}\mathrm{A} G \\
\text { Ratio }\end{array}$} \\
\hline & & & & \multicolumn{2}{|c|}{$\alpha_{1}$} & & \multicolumn{2}{|c|}{$a_{2}$} & \multicolumn{2}{|c|}{$\beta$} & \multicolumn{2}{|c|}{$\mathbf{M}$} & & \multicolumn{2}{|c|}{$\gamma$} & \\
\hline \multicolumn{17}{|c|}{ Type I } \\
\hline $\begin{array}{r}1 \\
2 \\
3 \\
4 \\
5 \\
6 \\
7 \\
8 \\
9 \\
10 \\
11\end{array}$ & $\begin{array}{r}13 \cdot 6 \\
11 \cdot 0 \\
10 \cdot 2 \\
12 \cdot 2 \\
8 \cdot 5 \\
9 \cdot 0 \\
10 \cdot 5 \\
9 \cdot 9 \\
7 \cdot 0 \\
5 \cdot 4 \\
4 \cdot 0\end{array}$ & $\begin{array}{l}21 \cdot 5 \\
16 \cdot 7 \\
20 \cdot 0 \\
28 \cdot 3 \\
23 \cdot 5 \\
25 \cdot 0 \\
39 \cdot 7 \\
33.9 \\
34 \cdot 0 \\
32.6 \\
45 \cdot 3\end{array}$ & $\begin{array}{l}2 \cdot 92 \\
1 \cdot 85 \\
2 \cdot 03 \\
3 \cdot 44 \\
2 \cdot 00 \\
2 \cdot 22 \\
4 \cdot 16 \\
3 \cdot 36 \\
2 \cdot 38 \\
1 \cdot 77 \\
1 \cdot 81\end{array}$ & $\begin{array}{r}2 \cdot 7 \\
2 \cdot 6 \\
4 \cdot 3 \\
2 \cdot 6 \\
4 \cdot 6 \\
2 \cdot 6 \\
3 \cdot 5 \\
4 \cdot 2 \\
2 \cdot 6 \\
10 \cdot 4 \\
7 \cdot 3\end{array}$ & $\begin{array}{l}0.36 \\
0.28 \\
0.45 \\
0.33 \\
0.39 \\
0.23 \\
0.37 \\
0.41 \\
0.18 \\
0.56 \\
0.29\end{array}$ & 1 & $\begin{array}{r}3 \cdot 8 \\
3 \cdot 6 \\
5 \cdot 6 \\
7 \cdot 0 \\
1 \cdot 9 \\
5 \cdot 2 \\
6 \cdot 2 \\
6 \cdot 6 \\
3 \cdot 1 \\
11 \cdot 3 \\
6 \cdot 2\end{array}$ & $\begin{array}{l}0.52 \\
0.37 \\
0.57 \\
0.85 \\
0.17 \\
0.47 \\
0.65 \\
0.66 \\
0.22 \\
0.60 \\
0.25\end{array}$ & $\begin{array}{r}4 \cdot 4 \\
5 \cdot 5 \\
6 \cdot 7 \\
12 \cdot 1 \\
3 \cdot 5 \\
5 \cdot 1 \\
4 \cdot 2 \\
7 \cdot 2 \\
8 \cdot 1 \\
9 \cdot 7 \\
7 \cdot 3\end{array}$ & $\begin{array}{l}0.60 \\
0.61 \\
0.68 \\
1.48 \\
0.29 \\
0.46 \\
0.44 \\
0.72 \\
0.57 \\
0.52 \\
0.29\end{array}$ & 1 & & & $\begin{array}{l}67 \cdot 6 \\
71 \cdot 6 \\
63 \cdot 4 \\
50 \cdot 0 \\
66 \cdot 5 \\
62 \cdot 1 \\
46 \cdot 4 \\
48 \cdot 1 \\
52 \cdot 2 \\
36 \cdot 0 \\
33 \cdot 9\end{array}$ & $\begin{array}{l}9 \cdot 20 \\
7.90 \\
6.47 \\
6 \cdot 10 \\
5.65 \\
5.62 \\
4.88 \\
4.75 \\
3.65 \\
1.95 \\
1.36\end{array}$ & $\begin{array}{l}0.27 \\
0.23 \\
0.25 \\
0.39 \\
0.31 \\
0.33 \\
0.65 \\
0.51 \\
0.51 \\
0.48 \\
0.83\end{array}$ \\
\hline $\begin{array}{l}12 \\
13 \\
14 \\
15\end{array}$ & $\begin{array}{r}11.8 \\
8.0 \\
8 \cdot 5 \\
10.6\end{array}$ & $\begin{array}{l}20 \cdot 7 \\
46 \cdot 0 \\
47 \cdot 3 \\
25 \cdot 6\end{array}$ & $\begin{array}{l}2 \cdot 43 \\
3 \cdot 68 \\
4 \cdot 01 \\
2 \cdot 71\end{array}$ & $\begin{array}{l}5 \cdot 0 \\
5 \cdot 6 \\
4 \cdot 1 \\
2 \cdot 2\end{array}$ & $\begin{array}{l}0.59 \\
0.45 \\
0.35 \\
0.24\end{array}$ & & $\begin{array}{l} \\
5 \cdot 3 \\
8 \cdot 0 \\
7 \cdot 7 \\
3 \cdot 9\end{array}$ & $\begin{array}{c}\text { Гуре II } \\
0.62 \\
0.64 \\
0.65 \\
0.42\end{array}$ & $\begin{array}{r}6 \cdot 4 \\
6 \cdot 2 \\
22 \cdot 0 \\
65 \cdot 6\end{array}$ & $\begin{array}{l}0.75 \\
0.50 \\
1.87 \\
6.95\end{array}$ & $\begin{array}{l}46 \cdot 2 \\
32 \cdot 8\end{array}$ & $\begin{array}{l}5 \cdot 45 \\
2 \cdot 62\end{array}$ & 1 & $\begin{array}{r}16.4 \\
1.4 \\
18.9 \\
2.7\end{array}$ & $\begin{array}{l}1.96 \\
0.11 \\
1.62 \\
0.28\end{array}$ & $\begin{array}{l}0.30 \\
0.85 \\
0.89 \\
0.34\end{array}$ \\
\hline \multicolumn{17}{|c|}{ Type III } \\
\hline 16 & $5 \cdot 6$ & i 54.0 & $3 \cdot 01$ & $9 \cdot 1$ & 0.52 & 1 & $11 \cdot 6$ & 0.65 & $112 \cdot 9$ & $0 \cdot 72$ & 1 & & 1 & $12 \cdot 4$ & 0.69 & $1 \cdot 17$ \\
\hline \multicolumn{17}{|c|}{ Type IV } \\
\hline $\begin{array}{l}17 \\
18 \\
19 \\
20\end{array}$ & $\begin{array}{l}7 \cdot 7 \\
5 \cdot 1 \\
6 \cdot 0 \\
6 \cdot 6\end{array}$ & $\begin{array}{l}33 \cdot 6 \\
44 \cdot 3 \\
44 \cdot 0 \\
39 \cdot 0\end{array}$ & $\begin{array}{l}2 \cdot 59 \\
2 \cdot 23 \\
2 \cdot 64 \\
2 \cdot 58\end{array}$ & $\begin{array}{r}5 \cdot 0 \\
9 \cdot 3 \\
7 \cdot 2 \\
10 \cdot 7\end{array}$ & $\begin{array}{l}0.38 \\
0.47 \\
0.42 \\
0.70\end{array}$ & & $\begin{array}{l}47 \cdot 9 \\
25 \cdot 7 \\
19 \cdot 9 \\
17 \cdot 4\end{array}$ & $\begin{array}{l}3 \cdot 68 \\
1 \cdot 35 \\
1 \cdot 19 \\
1 \cdot 16\end{array}$ & $\begin{array}{l}10 \cdot 6 \\
11 \cdot 2 \\
19 \cdot 7 \\
16 \cdot 7\end{array}$ & $\begin{array}{l}0 \cdot 83 \\
0 \cdot 56 \\
1 \cdot 19 \\
1 \cdot 10\end{array}$ & & & & $\begin{array}{r}2 \cdot 9 \\
9 \cdot 5 \\
9 \cdot 2 \\
16 \cdot 2\end{array}$ & $\begin{array}{l}0.22 \\
0.48 \\
0.57 \\
1.06\end{array}$ & $\begin{array}{l}0.50 \\
0.79 \\
0.78 \\
0.64\end{array}$ \\
\hline
\end{tabular}

from three urines. Table I shows the figures derived from these. It can be seen that there are 11 cases which belong to Gutman's type I, four to type II, and one to type III. In addition there are four sera belonging to a new type which we propose calling Type IV and define as " those sera which possess a globulin fraction which migrates between the albumin and beta fractions." It will be noted that the sera of type IV have low total proteins, decreased amounts of albumin, and normal alpha 1 and beta fractions. In three the gamma globulin fraction is below the normal values and in one it is normal.

Nine patients had protein in the urine. Numbers 4,5 , and 9 had traces of Bence Jones protein. Number 13 (100 mg. per $100 \mathrm{ml}$.), No. 14 (1.3 g. per $100 \mathrm{ml}$.$) , and No. 16(1.1 \mathrm{~g}$. per $100 \mathrm{ml}$.) had a protein which had the same mobility as gamma globulin. Of the four patients in Type IV, No. 20 had no protein in the urine and the other three showed very small amounts. All urines were concentrated by dialysis and on electrophoresis showed very different patterns. No. 17 showed three large peaks, a small one with the same mobility as albumin, a much larger peak migrating with the mobility of alpha 2 globulin, and a trace corresponding with the gamma fraction. The total urinary protein in this case was $0.25 \mathrm{~g}$. $/ 100 \mathrm{ml}$. No. 18 , with a total protein of $0.7 \mathrm{~g}$. per $100 \mathrm{ml}$., showed two peaks consisting of $25.9 \%$ albumin and $59.5 \%$ gamma globulin. No. 19 , with a total protein of $0.55 \mathrm{~g}$. per $100 \mathrm{ml}$., showed one solitary peak which migrated between the beta and gammao positions (Fig. 1).

Since all strips were run at $p \mathbf{H} 8.6$, gammå globu'in is negatively charged and moves towards $\vec{\circ}$ the anode, but, owing to endosmosis, its final posi-3 tion is some distance to the cathode side of the line? marking the site of inoculation. It will be noted? that there are three types of gamma globulin, oneत which has the same mobility as a normal gamma:fraction while the others occupy positions either 3 to the right or left of this position. These are noto confined to any one type but are scattered indis-3 criminately over the four types.

Flocculation tests were carried out on 13 subjects of this series, and the results are shown in Table II. The normal values of the tests are as follows :

\begin{tabular}{|c|c|c|}
\hline Test & Reference & $\begin{array}{c}\begin{array}{c}\text { Normal } \\
\text { Value }\end{array} \\
\text { (g. } / 100 \mathrm{ml} .)\end{array}$ \\
\hline $\begin{array}{l}\text { Colloidal gold . } \\
\text { Thymol turbidity } \\
\text { Thymol flocculation } \\
\text { Zinc sulphate (Kunkel) } \\
\begin{array}{l}\text { Ammonium sulphate } \\
\text { (Popper) }\end{array}\end{array}$ & $\begin{array}{l}\text { Maclagan (1944a) } \\
\qquad, \quad(1944 b) \\
\text { Kunkel (1947) } \\
\text { Ku } \quad(1947) \\
\text { de la Heurga and Popper } \\
\quad(1950)\end{array}$ & $\begin{array}{l}0 \\
0-2 \\
0-1 \\
2-12 \\
0-6\end{array}$ \\
\hline
\end{tabular}

These are the original Kunkel and Popper tests $\frac{?}{\mathbb{D}}$ and not as subsequently modified by Maclagan.

Maclagan, Martin, and Lunnon (1952) reporting? on a similar series of 14 cases, state that when the 
TABLE II

RESULTS OF FLOCCULATION TESTS

\begin{tabular}{|c|c|c|c|c|c|}
\hline $\begin{array}{l}\text { Case } \\
\text { No. }\end{array}$ & $\begin{array}{l}\text { Colloidal } \\
\text { Gold }\end{array}$ & $\begin{array}{l}\text { Thymol } \\
\text { Turbidity }\end{array}$ & $\begin{array}{c}\text { Thymol } \\
\text { Flocculation }\end{array}$ & Kunkel & Poppar \\
\hline $\begin{array}{r}1 \\
4 \\
5 \\
6 \\
7 \\
10 \\
11\end{array}$ & $\begin{array}{l}5^{*} \\
5 \\
0 \\
0 \\
1 \\
2\end{array}$ & $\begin{array}{r}36 \\
\frac{24}{24}^{*} \\
1 \\
3 \\
21\end{array}$ & | $\begin{array}{r}\text { Type I } \\
4 \\
-{ }^{*} \\
4 \\
0 \\
0 \\
0 \\
-t\end{array}$ & $\begin{array}{c}96 \\
\overline{44}^{*} \\
23 \\
48 \\
19 \\
8\end{array}$ & $\begin{array}{c}52 \\
\frac{1}{30}^{*} \\
18 \\
17 \\
8 \\
7\end{array}$ \\
\hline $\begin{array}{l}13 \\
14\end{array}$ & $\begin{array}{l}0 \\
0\end{array}$ & $\begin{array}{l}1 \\
5\end{array}$ & 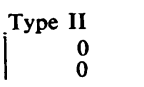 & $\begin{array}{l}0 \\
7\end{array}$ & $\begin{array}{r}16 \\
3\end{array}$ \\
\hline 16 & 0 & 2 & $\mathrm{i}^{\text {Type III }}$ & 2 & 1 \\
\hline $\begin{array}{l}17 \\
18 \\
19\end{array}$ & $\begin{array}{l}0 \\
0 \\
0\end{array}$ & $\begin{array}{l}1 \\
1 \\
1\end{array}$ & 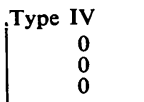 & $\begin{array}{l}0 \\
2 \\
1\end{array}$ & $\begin{array}{l}1 \\
2 \\
1\end{array}$ \\
\hline
\end{tabular}

* Immediate flocculation, impossible to read. † Redissolved.

Kunkel test is negative the gold and thymol tests are also negative, whereas when the thymol test is positive all the other tests are positive. These statements are not correct for our series. While it is true that in two cases where the Kunkel test was negative the thymol test was also negative, Case 13 had a positive Popper reaction. This, as we have stated before (Griffiths and Gilchrist, 1953), is due to the fact that the Popper test will also precipitate fibrinogen-like proteins, and our Case 13 had $32 \%$ of $M$ protein. In Case 14 the thymol test is positive but the gold and thymol flocculation tests are negative, contrary to the findings of Maclagan et al. (1952). When the cases are arranged in the four types (Table II) it can be seen that the majority of the positive results occur in Type I. This is to be expected as these are all cases with a marked increase in gamma globulins. In Type II, where the abnormal protein has migrated from the gamma position, the results are more normal, while with Types III and IV they are entirely normal. It would appear that the observed dissociation of the flocculation tests in multiple myelomata is due to the fact that these tests were originally designed to detect gamma globulins and the more an abnormal protein departs from similarity with the gamma fraction the less likely are these tests to yield a positive result.

\section{Summary}

The electrophoretic patterns in 20 cases of multiple myelomatosis are described. Eleven belong to Gutman's Type I, four to Type II, one to Type III, and four to Type IV, a type not described by Gutman.

The distinguishing features of the new type (Type IV) are described.

Flocculation tests obtained in 13 of these cases are compared and a possible explanation is given for the observed dissociation.

Our thanks are due to our colleagues who, knowing our interest, sent many cases to us, and also to Mr. E. Poynter, the group photographer, for the photographic reduction of the electrophoretic patterns.

\section{REFERENCES}

Bing, J. (1940). Acta med. scand, 103, 547.

Flynn, F. V., and Mayo, P. de (1951). Lancet, 2, 235.

Griffiths, L. L. (1952). Journal of Clinical Pathology, 2, 294.

- (1953). J. Lab. clin. Med., 41, 188.

- and Gilchrist, L. (1953). Lancet (In the press).

Gutman, A. B. (1948). Advanc. Protein Chem., 4, 155

Moore, D. H., Gutman, E. B., McClellan, V., and Kabat, E. A. (1941). J. clin. Invest., $20,765$.

Howe, P. E. (1921). J. biol. Chem., 49, 93.

Huerga. J. de la, and Popper, H. (1950). J. Lab. clin. Med., 35, 459.

Kekwick, R. A. (1940). J. Biochem., 34, 1248.

Kunkel, H. G. (1947). Proc. Soc. exp. Biol., N.Y., 66, 217.

Longsworth, L. G., Shedlovsky, T., and MacInnes, D. A. (1939). J. exp. Med., $70,399$.

Maclagan, N. F. (1944a). Brit. J. exp. Path., 25, 15. -(1944b). Ibid., 25, 234.

(1947). Brit. med.J., 2, 197.

- Martin, N. H., and Lunnon, J. B. (1952). Journal of Clinical Pathology, 5 , 1.

Mannack. J. R., and Hoch, H. (1749). Ibid., 2, !61

Moore, D. H., Kabat, E. A., and Gutman, A. B. (1943). J. clin. Invest., 22, 67.

Perlzweig, W. A., Delrue, G., and Geschickter, C. (1928). J. Amer. med. Ass., $90,755$.

Tise.ius, A. (1939-40). Harvey Lect., 35, 37.

Wuhrmann, F., Wunderly, C., and Wiedemann, E. (1948). Schweiz. med. Wschr., 78, 180. 